\title{
Penerapan Fatwa DSN MUI pada Pembiayaan Murabahah BPRS Hasanah Pekanbaru
}

\author{
Mohd. Winario, Husni Fuaddi \\ STEI Iqra Annisa Pekanbaru \\ mohd.winario@gmail.com
}

\begin{abstract}
The research was based on a phenomenon that occurred in the community on the response that murabahah financing in Islamic banks is the same as loan transactions at conventional banks. It is also supported by the existence of the MUI DSN fatwa regulating murabahah financing. This research aims to know whether implementing murabahah financing is based on Islamic principles and whether it is under the fatwa set by the DSN-MUI. This research was conducted at BPRS Hasanah Pekanbaru. This study employed a qualitative descriptive analysis. The sampling method used snowball sampling. This research used interviews, observation, and documentation to collect data. The results showed that PT. BPRS Hasanah Pekanbaru in implementing murabahah financing is under the DSN-MUI Fatwa. Hence, it is necessary to increase caution in its implementation so that BPRS will continue being consistent in its Syariah and captivate the hearts of customers.
\end{abstract}

Keywords: Application, Fatwa, DSN, Financing, Murabahah

\begin{abstract}
Abstrak
Penelitian didasari atas fenomena yang terjadi di masyarakat atas tanggapan bahwa pembiayaan murabahah di bank syariah adalah sama dengan bertransaksi pinjaman di bank konvensional, hal ini juga didukung dengan adanya fatwa DSN MUI yang mengatur pembiayaan murabahah. Penelitian ini dilaksanakan di BPRS Hasanah Pekanbaru, dengan tujuan mengetahui penerapan pembiayaan murabahah dalam penerapannya apakah sudah sesuai dengan fatwa yang telah ditetapkan oleh DSN-MUI. Metode pengambilan sampel penelitian ini dengan menggunakan snowball sampling, dengan cara interview, observasi dan dokumentasi. Penelitian ini menggunakan analisis deskriptif kualitatif. Hasil penelitian menunjukkan bahwa PT. BPRS Hasanah Pekanbaru dalam menerapkan pembiayaan Murabahah sudah sesuai dengan Fatwa DSN-MUI, sehingga perlu ditingkatkan kehati-hatian dalam pelaksanaanya supaya BPRS terus konsisten pada kesyariahannya dan mendapat hati di hati nasabah.
\end{abstract}

Kata Kunci: Penerapan, Fatwa, DSN, Pembiayaan, Murabahah 


\section{PENDAHULUAN}

Melihat Dewasa ini, salah satu tanda kebangkitan Islam adalah lahirnya lembaga-lembaga keuangan Islam. Di antara lembaga keuangan Islam yang lahir adalah Perbankan Islam (Islamic Banking). Sejak pertengahan 1970-an, perbankan Islam telah meluas dan sudah beroperasi lebih dari 70 negara meliputi sebagian besar dunia muslim pada tahun 1997 aset total bank-bank yang melaporkan data keuangannya ke Internastional Association of Islamic Banks (IAIB) sebanyak 176 bank adalah US \$ 148 milyar (Latifa M. Al-Gaoud dan Mervyn K. Lewis, 2004: 23-24).

Berdasarkan beberapa estimasi tertentu yang mungkin terlalu optimis lebih dari setengah simpanan tabungan dunia Islam di masa mendatang akan dikelola oleh institusi-institusi keuangan Islam. (Ibrahim Warde: 2009: 1).

Perkembangan sampai kepada prediksi masa mendatang di Indonesia, gagasan untuk mendirikan bank syariah sebenarnya sudah muncul sejak pertengahan tahun 1970-an, namun belum terealisasi. Pada akhirnya gagasan tersebut muncul lagi pada tahun 1988, dan pada tahun 1991 ditandatanganilah akte pendirian PT. Bank Mu'amalat Indonesia. (Heri Sudarsono, 2004: 31). Dan setelah itu, lahirlah bermacam-macam lembaga keuangan syariah baik berbentuk bank maupun non bank seperti BPRS (Bank Pembiayaan Rakyat Syariah), BMT (Baitul Mal Watamwil), Kopsyah (Koperasi Syariah), KJKS (Kopersi Jasa Keuangan Syariah), Pegadaian Syariah, Asuransi Syariah, Leasing Syariah dan lain-lain dan bahkan bank-bank yang menggunakan sistem bunga pun menginvansi-kan sayapnya membuka cabang syariah atau Unit Usaha Syariah (UUS). Bahkan ada yang langsung menjadi Bank Umum Syariah.

Pada perbankan syariah banyak sekali akad-akad berdasarkan akad syariah, diantaranya funding (Penghimpunan Dana), financing (Penyaluran Dana), dan Fee Based Service (Multijasa Perbankan). Funding diantaranya Wadiah dan Mudharabah, Financing yang berbentuk jual beli; Murabahah, Salam, Istishna, yang berbentuk bagi hasil; mudharabah, musyarakah, dan yang berbentuk sewa menyewa; ijarah. Sedangkan yang berbentuk feebased services; hiwalah, rahn, Kafalah, sharf, serta transaksi kartu kredit syariah. 
Pada perbankan syariah, baik itu bank umum maupun BPRS dalam akad pembiayaan/penyaluran dana tidak akan terlepas dari akad jual beli atau murabahah. Bahkan akad murabahah menempati urutan yang terbesar dalam penyaluran dananya ke nasabah. Selain mudah diterapkan baik bagi pihak bank maupun nasabahnya.

Jual beli ini dibagi oleh para fuqaha' ke dalam beberapa pembagian, adapun berdasarkan pada cara penetapan harga produk jual beli tersebut dibagi kepada tiga macam yaitu: musawamah, muzayadah dan amanah. Jual beli amanah dibagi lagi kepada tiga macam yaitu murabahah, tauliyah dan wadh'iyah. Dengan demikian, pembiayaan murabahah sesungguhnya adalah salah satu bentuk jual beli.

Dalam pandangan Islam murabahah pada dasarnya berarti penjualan. Satu hal yang membedakannya dengan cara penjualan yang lain adalah bahwa penjual dalam model murabahah secara jelas memberi tahu kepada pembeli berapa nilai pokok barang tersebut dan berapa besar keuntungan yang dibebankannya pada nilai tersebut. Keuntungan bisa berupa lump sum atau berdasarkan persentase. (Adrian Sutedi, 2009: 95.)

Sesuai dengan Fatwa DSN-MUI No. 04/DSN/MUI/2000, yang telah difatwakan oleh Majelis Ulama Indonesia sejak tahun 2000, bahwa pembiayaan murabahah diperbolehkan, oleh karena itu penulis ingin melihat penerapan di lembaga keuangan syariah. Untuk mempermudah dalam penelitian ini, penulis mengambil satu bentuk lembaga bank yaitu BPRS (Bank Pembiayaan Rakyat Syariah), dalam hal ini adalah Bank Pembiayaan Rakyat Syariah Hasanah (BPRS Hasanah). BPRS Hasanah merupakan satu-satunya BPRS yang ada di Pekanbaru, karena di Riau hanya ada dua BPRS yaitu BPRS Hasanah Pekanbaru dan BPRS Berkah Dana Fadhlillah di Kabupaten Kampar.

Untuk memahami pembiayaan murabahah berdasarkan jumlah pembiayaan dan jangka waktu pembiayaannya di PT BPRS Hasanah Pekanbaru dapat dilihat pada tabel 1 di bawah ini: 
Tabel 1

Ilustrasi/Simulasi Angsuran Pembiayaan Murabahah PT. BPRS Hasanah Pekanbaru

\begin{tabular}{rrrrrr}
\hline No & Plafond & \multicolumn{4}{c}{ Jangka Waktu - Bulan } \\
\cline { 3 - 6 } & & $\mathbf{1 2}$ & $\mathbf{2 4}$ & $\mathbf{3 0}$ & $\mathbf{3 6}$ \\
1 & 16.000 .000 & 1.541 .333 & 874.667 & 741.333 & 652.444 \\
2 & 17.000 .000 & 1.637 .667 & 929.333 & 787.667 & 693.222 \\
3 & 18.000 .000 & 1.734 .000 & 984.000 & 834.000 & 734.000 \\
4 & 19.000 .000 & 1.830 .333 & 1.038 .667 & 880.333 & 774.778 \\
5 & 20.000 .000 & 1.926 .667 & 1.093 .333 & 926.667 & 815.556 \\
6 & 21.000 .000 & 2.023 .000 & 1.148 .000 & 973.000 & 856.333 \\
7 & 22.000 .000 & 2.119 .333 & 1.202 .667 & 1.019 .333 & 897.111 \\
8 & 23.000 .000 & 2.215 .667 & 1.257 .333 & 1.065 .667 & 937.889 \\
9 & 24.000 .000 & 2.312 .000 & 1.312 .000 & 1.112 .000 & 978.667 \\
10 & 25.000 .000 & 2.408 .333 & 1.366 .667 & 1.158 .333 & 1.019 .444 \\
\hline
\end{tabular}

Sumber: BPRS Hasanah Pekanbaru

PT. BPRS Hasanah menentukan margin pembiayaan murabahah untuk individu sebesar $1.6 \%$ Perbulan, jadi selama 1 tahun nasabah dikenakan margin sebesar $19.20 \%$. Sedangkan untuk Instansi atau lembaga yang melakukan kerjasama dengan PT. BPRS Hasanah nasabah dikenakan 1.5\% Perbulan atau 18\% Pertahunnya. (Wawancara dengan Bapak Edwin Hendra Bagian Pembiayaan BPRS Hasanah).

Berdasarkan latar belakang tersebut, maka penulis merumuskan masalah dalam penelitian ini adalah bagaimana penerapan fatwa DSN MUI pada pembiayaan murabahah yang diterapkan BPRS Hasanah Pekanbaru. 


\section{KERANGKA TEORI}

\section{Pembiayaan}

Pembiayaan menurut Antonio, merupakan salah satu tugas pokok bank, yaitu pemberian fasilitas penyediaan dana untuk memenuhi kebutuhan pihakpihak yang merupakan defisit unit. (Muhammad Syafi'i Antonio, 2001: 161-168.)

Pembiayaan adalah penyediaan dana atau tagihan yang dipersamakan dengan itu berupa:

a. Transaksi bagi hasil dalam bentuk mudharabah dan musyarakah.

b. Transaksi sewa-menyewa dalam bentuk ijarah atau sewa beli dalam bentuk ijarah muntahiya bittamlik.

c. Transaksi jual beli dalam bentuk piutang murabahah, salam, dan istishna'.

d. Transaksi pinjam meminjam dalam bentuk piutang qardh; dan

e. Transaksi sewa-menyewa jasa dalam bentuk ijarah untuk transaksi multijasa.

Berdasarkan persetujuan atau kesepakatan antara bank syariah dan atau UUS dan pihak lain yang mewajibkan pihak yang dibiayai dan atau diberi fasilitas dana untuk mengembalikan dana tersebut setelah jangka waktu tertentu dengan imbalan ujrah, tanpa imbalan, atau bagi hasil. (UUD No. 21 Tahun 2008).

\section{Murabahah}

Murabahah (مرابحة) secara bahasa bermakna pemberian keuntungan. Kata Murabahah (مرابحة) merupakan salah satu contoh dari wazan مفاعلة, yang berasal dari kata الربح الربح maknanya adalah النماء في التجر (pertumbuhan dalam perdagangan). (Ibnu Manzhur, 2005: 223). Maka bagi orang Arab seseorang itu dianggap untung kalau aset dagangannya tumbuh/bertambah, hal ini senada dengan ayat Al-qur'an;

Artinya: "Mereka Itulah orang yang membeli kesesatan dengan petunjuk, Maka tidaklah beruntung perniagaan mereka dan tidaklah mereka mendapat petunjuk." (QS. Al-Baqarah: 16). 
Ketika disebutkan pembayaran produk ini adalah dengan cara murabahah dimana setiap sepuluh dirham diambil keuntungan satu dirham atau ketika seseorang berkata saya menjualnya dengan cara murabahah maka orang tersebut harus menyebutkan keuntungan yang ia ambil. Oleh sebab itu, dalam akad murabahah penyebutan jumlah keuntungan yang diambil oleh penjual adalah sebuah kemestian.

Dalam kitab Al-Hidayah disebutkan bahwa definisi murabahah adalah perpindahan sesuatu yang dimiliki dengan akad yang pertama dan harga yang pertama ditambah dengan keuntungan. (Ibnu Manzhur, 2005: 22). Al-Kasani mendefinisikan murabahah yaitu jual beli dengan harga pembelian pertama ditambah keuntungan. (Al-Kasany, 2005: 7/137).

Dalam kitab Al-Mughny, definisi murabahah adalah jual beli dengan modal ditambah keuntungan. (Ibnu Qudamah, 2005: 5/362).

Dalam kitab Al-Majmu' disebutkan bahwa murabahah adalah akad yang didasarkan pada harga yaitu harga pertama ditambah keuntungan misalnya seseorang membeli sebuah barang dengan harga Rp 100,-00 kemudian dia berkata kepada orang lain saya menjual barang ini kepadamu dengan harga pembelianku ditambah keuntungan. (An-Nawawy, 2004: 13/3).

Ulama Malikiyah mendefinisikan murabahah yaitu penjual memberitahukan harga pembeliannya dan mengambil keuntungan dari harga tersebut baik secara umum seperti keuntungan satu dinar, terperinci seperti setiap satu dinar beri keuntungan satu dirham atau dengan ukuran seper sepuluh. (Kementerian Wakaf dan Urusan Islam, 2006: 318).

\section{Metode Pengambilan Keuntungan Dalam Murabahah}

Metode Penentuan Margin menurut Muhammad adalah sebagai berikut Metode penentuan margin terdiri dari: (Muhammad 2005:132)

a. Mark up Pricing, Mark up pricing adalah penentuan tingkat harga dengan memarkup biaya produksi komoditas yang bersangkutan.

b. Target Return Pricing, Target Return Pricing adalah harga jual produk yang bertujuan mendapatkan tingkat return atas besarnya modal yang 
dïnvestasikan. Dalam bahasan keuangan dikenal dengan return on investment (ROI). Dalam hal ini perusahaan akan menentukan berapa return yang akan diharapkan atas modal yang dïnvestasikan.

c. Perceived Value Pricing, Received-Value Pricing adalah penentuan harga dengan tidak menggunakan variabel harga sebagai harga jual. Harga jual didasarkan pada harga produk pesaing dimana perusahaan melakukan penambahan atau perbaikan unit untuk meningkatkan kepuasan pembeli.

d. Value Pricing, Value Pricing adalah kebijakan harga yang kompetitif atas barang yang berkualitas tinggi. Dengan ungkapan ono rego ono rupo, artinya: barang yang baik pasti harganya mahal.

\section{Fatwa Murabahah DSN MUI}

a. Ketentuan Umum Murabahah dalam Bank Syariah

1) Bank dan nasabah harus melakukan akad murabahah yang bebas riba.

2) Barang yang diperjualbelikan tidak diharamkan oleh syariah Islam.

3) Bank membiayai sebagian atau seluruh harga pembelian barang yang telah disepakati kualifikasinya.

4) Bank membeli barang yang diperlukan nasabah atas nama bank sendiri, dan pembelian ini harus sah dan bebas riba.

5) Bank harus menyampaikan semua hal yang berkaitan dengan pembelian, misalnya jika pembelian dilakukan secara utang.

6) Bank kemudian menjual barang tersebut kepada nasabah (pemesan) dengan harga jual senilai harga beli plus keuntungannya. Dalam kaitan ini bank harus memberitahu secara jujur harga pokok barang kepada nasabah berikut biaya yang diperlukan.

7) Nasabah membayar harga barang yang telah disepakati tersebut pada jangka waktu tertentu yang telah disepakati.

8) Untuk mencegah terjadinya penyalahgunaan atau kerusakan akad tersebut, pihak bank dapat mengadakan perjanjian khusus dengan nasabah. 
9) Jika bank hendak mewakilkan kepada nasabah untuk membeli barang dari pihak ketiga, akad jual beli murabahah harus dilakukan setelah barang, secara prinsip, menjadi milik bank.

b. Ketentuan Murabahah Kepada Nasabah

1) Nasabah mengajukan permohonan dan janji pembelian suatu barang atau aset kepada bank.

2) Jika bank menerima permohonan tersebut, ia harus membeli terlebih dahulu aset yang dipesannya secara sah dengan pedagang.

3) Bank kemudian menawarkan aset tersebut kepada nasabah dan nasabah harus menerima (membeli)-nya sesuai dengan janji yang telah disepakatinya, karena secara hukum janji tersebut mengikat; kemudian kedua belah pihak harus membuat kontrak jual beli.

4) Dalam jual beli ini bank dibolehkan meminta nasabah untuk membayar uang muka saat menandatangani kesepakatan awal pemesanan.

5) Jika nasabah kemudian menolak membeli barang tersebut, biaya riil bank harus dibayar dari uang muka tersebut.

6) Jika nilai uang muka kurang dari kerugian yang harus ditanggung oleh bank, bank dapat meminta kembali sisa kerugiannya kepada nasabah.

7) Jika uang muka memakai kontrak ' urbun sebagai alternatif dari uang muka, maka:

a) Jika nasabah memutuskan untuk membeli barang tersebut, ia tinggal membayar sisa harga.

b) Jika nasabah batal membeli, uang muka menjadi milik bank maksimal sebesar kerugian yang ditanggung oleh bank akibat pembatalan tersebut; dan jika uang muka tidak mencukupi, nasabah wajib melunasi kekurangannya.

c. Jaminan dalam Murabahah:

1) Jaminan dalam murabahah dibolehkan, agar nasabah serius dengan pesanannya. 
2) Bank dapat meminta nasabah untuk menyediakan jaminan yang dapat dipegang.

d. Utang dalam murabahah:

1) Secara prinsip, penyelesaian utang nasabah dalam transaksi murabahah tidak ada kaitannya dengan transaksi lain yang dilakukan nasabah dengan pihak ketiga atas barang tersebut. Jika nasabah menjual kembali barang tersebut dengan keuntungan atau kerugian, ia tetap berkewajiban untuk menyelesaikan utangnya kepada bank.

2) Jika nasabah menjual barang tersebut sebelum masa angsuran berakhir, ia tidak wajib segera melunasi seluruh angsurannya.

3) Jika penjualan barang tersebut menyebabkan kerugian, nasabah tetap harus menyelesaikan utangnya sesuai kesepakatan awal. Ia tidak boleh memperlambat pembayaran angsuran atau meminta kerugian itu diperhitungkan.

e. Penundaan pembayaran dalam murabahah

1) Nasabah yang memiliki kemampuan tidak dibenarkan menunda penyelesaian utangnya.

2) Jika nasabah menunda-nunda pembayaran dengan sengaja, atau jika salah satu pihak tidak menunaikan kewajibannya, maka penyelesaiannya dilakukan melalui Badan Arbitrasi Syariah setelah tidak tercapai kesepakatan melalui musyawarah.

f. Bangkrut dalam Murabahah

Jika nasabah telah dinyatakan pailit dan gagal menyelesaikan utangnya, bank harus menunda tagihan utang sampai ia menjadi sanggup kembali, atau berdasarkan kesepakatan. (Fatwa DSN MUI No: 04/DSN-MUI/IV/2000). 


\section{Uang Muka Dalam Murabahah}

a. Ketentuan Umum

1) Dalam akad pembiayaan murabahah, lembaga keuangan syariah (LKS) dibolehkan untuk meminta uang muka apabila kedua belah pihak bersepakat.

2) Besar jumlah uang muka ditentukan berdasarkan kesepakatan.

3) Jika nasabah membatalkan akad murabahah, nasabah harus memberikan ganti rugi kepada LKS dari uang muka tersebut.

4) Jika jumlah uang muka lebih kecil dari kerugian, LKS dapat meminta tambahan kepada nasabah.

5) Jika jumlah uang muka lebih besar dari kerugian, LKS harus mengembalikan kelebihannya kepada nasabah.

6) Jika salah satu pihak tidak menunaikan kewajibannya atau jika terjadi perselisihan di antara kedua belah pihak, maka penyelesaiannya dilakukan melalui badan arbitrasi syariah setelah tidak tercapai kesepakatan melalui musyawarah.

7) Fatwa ini berlaku sejak tanggal ditetapkan dengan ketentuan jika di kemudian hari ternyata terdapat kekeliruan, akan diubah dan disempurnakan sebagaimana mestinya. (Fatwa DSN MUI No: 13/DSNMUI/IX/2000).

\section{Diskon Dalam Murabahah Menurut Fatwa DSN MUI}

a) Ketentuan Umum

1) Harga (tsaman) dalam jual beli adalah suatu jumlah yang disepakati oleh kedua belah pihak, baik sama dengan nilai (qîmah) benda yang menjadi obyek jual beli, lebih tinggi maupun lebih rendah.

2) Harga dalam jual beli murabahah adalah harga beli dan biaya yang diperlukan ditambah keuntungan sesuai dengan kesepakatan.

3) Jika dalam jual beli murabahah LKS mendapat diskon dari supplier, harga sebenarnya adalah harga setelah diskon; karena itu, diskon adalah hak nasabah. 
4) Jika pemberian diskon terjadi setelah akad, pembagian diskon tersebut dilakukan berdasarkan perjanjian (persetujuan) yang dimuat dalam akad.

5) Dalam akad, pembagian diskon setelah akad hendaklah diperjanjikan dan ditandatangani.

a) Jika salah satu pihak tidak menunaikan kewajibannya atau jika terjadi perselisihan diantara kedua belah pihak, maka penyelesaiannya dilakukan melalui Badan Arbitrasi Syariah setelah tidak tercapai kesepakatan melalui musyawarah.

b) Fatwa ini berlaku sejak tanggal ditetapkan dengan ketentuan jika di kemudian hari ternyata terdapat kekeliruan, akan diubah dan disempurnakan sebagaimana mestinya. (Fatwa DSN MUI No: 16/DSNMUI/IX/2000)

\section{Sanksi Atas Nasabah Mampu Yang Menunda-Nunda Pembayaran}

a. Ketentuan Umum

1) Sanksi yang disebut dalam fatwa ini adalah sanksi yang dikenakan LKS kepada nasabah yang mampu membayar, tetapi menunda-nunda pembayaran dengan disengaja.

2) Nasabah yang tidak atau belum mampu membayar disebabkan force majeur tidak boleh dikenakan sanksi.

3) Nasabah mampu yang menunda-nunda pembayaran dan atau tidak mempunyai kemauan dan itikad baik untuk membayar hutangnya boleh dikenakan sanksi.

4) Sanksi didasarkan pada prinsip ta'zir, yaitu bertujuan agar nasabah lebih disiplin dalam melaksanakan kewajibannya.

5) Sanksi dapat berupa denda sejumlah uang yang besarnya ditentukan atas dasar kesepakatan dan dibuat saat akad ditandatangani.

6) Dana yang berasal dari denda diperuntukkan sebagai dana sosial. 
b. Jika salah satu pihak tidak menunaikan kewajibannya atau jika terjadi perselisihan di antara kedua belah pihak, maka penyelesaiannya dilakukan melalui Badan Arbitrasi Syariah setelah tidak tercapai kesepakatan melalui musyawarah.

c. Fatwa ini berlaku sejak tanggal ditetapkan dengan ketentuan jika di kemudian hari ternyata terdapat kekeliruan, akan diubah dan disempurnakan sebagaimana mestinya. (Fatwa DSN MUI No: 17/DSN-MUI/IX/2000).

\section{Potongan Pelunasan Dalam Murabahah}

\section{Ketentuan Umum}

i. Jika nasabah dalam transaksi murabahah melakukan pelunasan pembayaran tepat waktu atau lebih cepat dari waktu yang telah disepakati, LKS boleh memberikan potongan dari kewajiban pembayaran tersebut, dengan syarat tidak diperjanjikan dalam akad

ii. Besar potongan sebagaimana dimaksud di atas diserahkan pada kebijakan dan pertimbangan LKS.

iii. Fatwa ini berlaku sejak tanggal ditetapkan dengan ketentuan jika di kemudian hari ternyata terdapat kekeliruan, akan diubah dan disempurnakan sebagaimana mestinya. (Fatwa DSN MUI No. 23/DSN-MUI/III/2002).

\section{Potongan Tagihan Murabahah (Khashm Fi Al-Murabahah)}

a.Ketentuan Pemberian Potongan

i. LKS boleh memberikan potongan dari total kewajiban pembayaran kepada nasabah dalam transaksi (akad) murabahah yang telah melakukan kewajiban pembayaran cicilannya dengan tepat waktu dan nasabah yang mengalami penurunan kemampuan pembayaran.

ii. Besar potongan sebagaimana dimaksud di atas diserahkan pada kebijakan LKS.

iii. Pemberian potongan tidak boleh diperjanjikan dalam akad. 
b. Ketentuan Penutup

i. Jika salah satu pihak tidak menunaikan kewajibannya atau jika terjadi perselisihan di antara pihak-pihak terkait, maka penyelesaiannya dilakukan melalui Badan Arbitrase Syariah Nasional setelah tidak tercapai kesepakatan melalui musyawarah.

ii. Fatwa ini berlaku sejak tanggal ditetapkan dengan ketentuan jika di kemudian hari ternyata terdapat kekeliruan, akan diubah dan disempurnakan sebagaimana mestinya. (Fatwa DSN MUI No. 46/DSN-MUI/II/2005)

\section{Penyelesaian Piutang Murabahah Bagi Nasabah Tidak Mampu Membayar}

a. Ketentuan penyelesaian

LKS boleh melakukan penyelesaian (settlement) murabahah bagi nasabah yang tidak bisa menyelesaikan atau melunasi pembiayaannya sesuai jumlah dan waktu yang telah disepakati, dengan ketentuan:

i. Obyek murabahah atau jaminan lainnya dijual oleh nasabah kepada atau melalui LKS dengan harga pasar yang disepakati;

ii. Nasabah melunasi sisa utangnya kepada LKS dari hasil penjualan;

iii. Apabila hasil penjualan melebihi sisa utang maka LKS mengembalikan sisanya kepada nasabah;

iv. Apabila hasil penjualan lebih kecil dari sisa utang maka sisa utang tetap menjadi utang nasabah;

v. Apabila nasabah tidak mampu membayar sisa utangnya, maka LKS dapat membebaskannya;

b. Ketentuan Penutup

i. Jika salah satu pihak tidak menunaikan kewajibannya atau jika terjadi perselisihan di antara pihak-pihak terkait, maka penyelesaiannya dilakukan melalui Badan Arbitrase Syariah Nasional setelah tidak tercapai kesepakatan melalui musyawarah.

ii. Fatwa ini berlaku sejak tanggal ditetapkan dengan ketentuan jika di kemudian hari ternyata terdapat kekeliruan, akan diubah dan 
disempurnakan sebagaimana mestinya. (Fatwa DSN MUI No. 47/DSNMUI/II/2005).

\section{Penjadwalan Kembali Tagihan Murabahah}

a. Ketentuan penyelesaian

LKS boleh melakukan penjadwalan kembali (rescheduling) tagihan murabahah bagi nasabah yang tidak bisa menyelesaikan/melunasi pembiayaannya sesuai jumlah dan waktu yang telah disepakati, dengan ketentuan:

i. Tidak menambah jumlah tagihan yang tersisa;

ii. Pembebanan biaya dalam proses penjadwalan kembali adalah biaya riil;

iii. Perpanjangan masa pembayaran harus berdasarkan kesepakatan kedua belah pihak.

b. Ketentuan Penutup

i. Jika salah satu pihak tidak menunaikan kewajibannya atau jika terjadi perselisihan di antara pihak-pihak terkait, maka penyelesaiannya dilakukan melalui Badan Arbitrase Syariah Nasional setelah tidak tercapai kesepakatan melalui musyawarah.

ii. Fatwa ini berlaku sejak tanggal ditetapkan dengan ketentuan jika di kemudian hari ternyata terdapat kekeliruan, akan diubah dan disempurnakan sebagaimana mestinya. (Fatwa DSN MUI No.48/DSNMUI/II/2005).

\section{METODE PENELITIAN}

Penelitian dilakukan di BPRS Hasanah Pekanbaru, Sumber data dari penelitian ini, data primer, yaitu data yang diperoleh dari BPRS Hasanah Pekanbaru dan data sekunder, yaitu data yang diperoleh dari buku-buku rujukan yang berhubungan dengan penelitian ini.

Teknik pengumpulan data yang penulis gunakan dalam penelitian ini dengan teknik wawancara, adalah dengan cara menanyakan langsung kepada pimpinan bank yang berkaitan dengan masalah yang penulis teliti, pengamatan 
atau observasi adalah dengan cara melihat langsung di bank tersebut, dan teknik dokumentasi, adalah dengan cara mengumpulkan dokumentasi dari bank, yang berhubungan dengan penelitian ini.

Populasi adalah jumlah keseluruhan dari satuan-satuan atau individuindividu yang karakteristiknya hendak diteliti. Dan satuan-satuan tersebut dinamakan unit analisis, dan dapat berupa orang-orang, institusi-institusi, bendabenda, dst. (Djarwanto, 1994: 420) Populasi dalam penelitian ini adalah Pimpinan dan Karyawan BPRS Hasanah Pekanbaru.

Sampel atau contoh adalah sebagian dari populasi yang karakteristiknya hendak diteliti. Djarwanto, (1994: 420) Adapun sampel dari penelitian ini adalah pimpinan BPRS Hasanah. Dalam penentuan sampel penelitian ini menggunakan metode snowball sampling.

Snowball sampling adalah teknik penentuan sampel yang mula-mula jumlahnya kecil, kemudian membesar. Ibarat bola salju yang menggelinding yang lama-lama menjadi besar. Dalam penentuan sampel, pertama-tama dipilih satu atau dua orang, tetapi karena dengan dua orang ini belum merasa lengkap terhadap data yang diberikan, maka peneliti mencari orang lain yang dipandang lebih tahu dan dapat melengkapi data yang diberikan oleh dua orang sebelumnya. Begitu seterusnya, sehingga jumlah sampel semakin banyak. (Sugiono, 2012: 68). Metode penelitian yang penulis gunakan dalam penulisan penelitian ini adalah menggunakan metode penelitian kualitatif.

\section{PEMBAHASAN}

\section{Analisis Pembiayaan Menggunakan Jaminan}

Dalam pembiayaan murabahah BPRS Hasanah Pekanbaru, pemberian pembiayaan dengan nominal tertentu tidak menggunakan jaminan berupa barang jaminan, namun hanya bentuk kerjasama dengan instansi saja dan jumlah pembiayaannya juga tidak terlalu banyak yaitu sebesar Rp. 5.000.000, kemudian jika jumlah pembiayaannya di atas Rp. 5.000.000, maka nasabah diwajibkan untuk memberikan jaminan di bank. Jaminan bisa berupa Sertifikat Hak Milik (SHM) Rumah, BPKB Kendaraan baik motor maupun mobil, SK Pegawai Negeri 
Sipil, dan lain-lain. (Wawancara dengan Bapak Edwin Hendra, Bagian Pembiayaan BPRS Hasanah)

Jadi dapat dijelaskan bahwa BPRS Hasanah meminta jaminan kepada nasabah pembiayaan murabahah kecuali kepada nasabah yang jumlah pembiayaannya dibawah Rp.5.000.000,- karena jumlah pembiayaan ini relatif kecil dengan resiko yang kecil juga. Pembiayaan itu juga sudah diikat dengan kerjasama dengan instansi dimana nasabah bekerja. Tindakan yang dilakukan oleh bank sudah sesuai dengan Fatwa DSN MUI No: 04/DSN-MUI/IV/2000. Tertuang dalam poin ketiga tentang jaminan dalam murabahah.।

\section{Analisis Jika Nasabah Pailit atau Bangkrut}

Dalam menghadapi masalah nasabah yang pailit atau bangkrut maka BPRS Hasanah mencari solusi dengan cara mengeksekusi jaminan yang telah diberikan oleh nasabah, jika penjualan jaminan uangnya berlebih dari jumlah pembiayaan maka akan dikembalikan kepada nasabah yang bersangkutan. (Wawancara dengan Bapak Edwin Hendra Bagian Pembiayaan BPRS Hasanah).

Sehingga dapat dijelaskan bahwa ketika nasabah pailit, maka BPRS mencari solusi terbaik dengan cara meminta kepada nasabah untuk menjual terlebih dahulu jaminannya, agar harga jual yang diperoleh bisa tinggi, jika nasabah tidak mau menjual, maka bank bisa menjualkan jaminan tersebut. Artinya bank akan mengeksekusi atau menjual jaminan yang telah dititipkan oleh nasabah di bank, jika ada sisa, maka uang tersebut dikembalikan kepada nasabah. Tindakan tersebut sudah sesuai dengan Fatwa DSN MUI No: 04/DSNMUI/IV/2000. Terdapat dalam poin keenam tentang bangkut dalam murabahah.

\section{Analisis Penggunaan Uang Muka Dalam Pembiayaan Murabahah}

Pada pembiayaan murabahah ini, BPRS Hasanah ada dua macam pembiayaan, yaitu pembiayaan murabahah yang menggunakan uang muka dan ada juga pembiayaan murabahah yang tidak menggunakan uang muka. (Wawancara dengan Bapak Edwin Hendra Bagian Pembiayaan BPRS Hasanah). 
Dari penjelasan tersebut dapat dijelaskan bahwa pembiayaan ini merupakan kebijakan dari BPRS Hasanah dalam pembiayaan murabahah, pada dasarnya bisa saja pembiayaan menerapkan salah satu atau keduanya, hal ini sesuai dengan Fatwa DSN MUI No. 13/DSN-MUI/IX/2000, pernyataan tersebut terdapat dalam poin kedua.

\section{Analisis Pemberian Diskon Dalam Pembiayaan Murabahah}

Pada dasarnya pemberian diskon diberikan oleh kepada nasabah merupakan sesuatu yang diharapkan oleh nasabah, namun saat ini dalam pelaksanaan pembiayaan murabahah yang dilakukan oleh BPRS Hasanah tidak ada memberikan diskon kepada nasabah. (Wawancara dengan Bapak Edwin Hendra Bagian Pembiayaan BPRS Hasanah).

Dari penjelasan tersebut di atas dapat dijelaskan bahwa BPRS Hasanah tidak memberikan fasilitas diskon kepada nasabahnya, ada pertimbangan tertentu yang dilakukan oleh bank kenapa tidak memberikan diskon kepada nasabah. Dalam Fatwa DSN MUI No: 16/DSN-MUI/IX/2000 dinyatakan sesuai dengan kesepakatan antara bank dan nasabah, jika tidak diberikan tidak menjadi masalah, asalkan kedua belah pihak telah mendapatkan kata sepakat.

\section{Sanksi Terhadap Nasabah Yang Menunda-nunda}

Sanksi terhadap nasabah yang menunda-nunda, BPRS Hasanah memberikan surat peringatan mulai dari SP1, SP2, SP3. Jika tidak merubah kebiasaan atau karakter nasabah, maka langkah berikutnya adalah dengan cara memberikan denda per hari kepada nasabah tersebut. Denda per hari itu karena termasuk dana yang dilarang syariah sehingga tidak bisa dimasukkan ke dalam pendapatan bank. Maka uang dari denda tersebut dipergunakan untuk keperluan fasilitas umum, kegiatan-kegiatan sosial, Corporate Social Responsibility (CSR), dan lain-lain. (Wawancara dengan Bapak Edwin Hendra Bagian Pembiayaan BPRS Hasanah).

Sehingga dapat dijelaskan bahwa menyelesaikan masalah ketika nasabah sengaja menunda-nunda pembayaran pembiayaan dengan cara memberikan efek 
jera supaya nasabah disiplin, yaitu dengan cara memberikan surat peringatan, mulai dari peringatan pertama, peringatan kedua, sampai peringatan ketiga, jika masih menunda-nunda, maka bank memberikan denda kepada nasabah yang bersangkutan. Tindakan yang dilakukan oleh BPRS Hasanah Pekanbaru sudah sesuai dengan Fatwa DSN MUI No: 17/DSN-MUI/IX/2000. Pada fatwa ini dijelaskan bahwa yang diperbolehkan adalah bagi nasabah yang mampu dan sengaja menunda-nunda pembayaran, maka boleh dikenakan denda.

\section{Analisis Jika Nasabah Melunasi Pembiayaan Murabahah Sebelum Jatuh Tempo}

Pada dasarnya Nasabah tidak mau berhutang kepada bank jika ada kelebihan dana. Karena kekurangan dana maka nasabah melakukan pembiayaan kepada BPRS Hasanah. Ketika nasabah telah ada dana untuk melunasi jumlah pembiayaan, maka nasabah akan membayar jumlah pembiayaan yang telah dilakukan.

Dalam hal ini pada pembiayaan murabahah yang dilakukan oleh BPRS Hasanah memberikan fasilitas potongan margin, ketika nasabah melunasi seluruh pembiayaan murabahahnya. Maksudnya adalah nasabah hanya membayar pokok pembiayaan tanpa membayar margin tiap bulannya, hanya saja nasabah diwajibkan membayar margin beberapa bulan saja. (Wawancara dengan Bapak Edwin Hendra Bagian Pembiayaan BPRS Hasanah).

Hal ini dapat dijelaskan bahwa BPRS Hasanah memberikan potongan berupa pembayaran pokok pembiayaan ditambah margin beberapa bulan saja, dan sisanya hanya dibayar pokoknya saja. Syaratnya tidak dijanjikan diawal ketika terjadinya akad antara bank dengan nasabah, hal ini sudah sesuai dengan Fatwa DSN MUI No. 23/DSN-MUI/III/2002.

\section{Analisis Penyelesaian Piutang Murabahah Jika Nasabah Tidak Mampu Membayar}

BPRS Hasanah dal hal ini memberikan sanksi bagi nasabah yang tidak sanggup membayar, berupa surat peringatan pertama, surat peringatan kedua, 
surat peringatan ketiga, dan terakhir eksekusi jaminan, namun bank tetap memberikan kesempatan kepada nasabah secara kekeluargaan, diskusi dengan nasabah bagaimana solusinya, bank juga memberikan kesempatan untuk penjualan jaminan dilakukan langsung oleh nasabah dan jika tidak terjual, maka bank akan mengambil alih dengan cara melelang jaminan tesebut. (Wawancara dengan Bapak Edwin Hendra Bagian Pembiayaan BPRS Hasanah).

Sehingga dapat dijelaskan bahwa langkah terakhir yang dilakukan oleh BPRS Hasanah dalam penyelesaian piutang murabahah jika nasabah tidak mampu membayar adalah menjual jaminannya. Hal ini sudah sesuai dengan Fatwa DSN MUI No. 47/DSN-MUI/II/2005 tentang penyelesaian piutang murabahah bagi nasabah tidak mampu membayar.

\section{Analisis Rescedulling Bank Terhadap Nasabah}

BPRS Hasanah akan memberikan rescedulling (penjadwalan kembali) atas nasabah yang tidak sanggup membayar dengan jumlah yang telah disepakati sebelumnya dengan berbagai pertimbangan, tanpa menambah pembiayaan dan tanpa menambah margin. Bank juga memberikan restructuring (penstruktur kembali) dan reconditioning (pengkondisian kembali) terhadap nasabah sesuai dengan kesepakatan. (Wawancara dengan Bapak Edwin Hendra Bagian Pembiayaan BPRS Hasanah).

Sehingga dapat dijelaskan bahwa bank memberikan kesempatan kepada nasabah untuk bernegosiasi melakukan rescedulling angsuran pembiayaan. Hal ini sudah sesuai dengan Fatwa DSN MUI No.48/DSN-MUI/II/2005.

\section{KESIMPULAN}

Berdasarkan rumusan masalah dalam penelitian ini penerapan fatwa DSN MUI pada pembiayaan Murabahah BPRS Hasanah, penulis mengambil kesimpulan dari uraian penelitian ini adalah bahwa PT. BPRS Hasanah Pekanbaru dalam menerapkan pembiayaan Murabahah sudah sesuai dengan Fatwa DSNMUI. Dalam pelaksanaannya diharapkan BPRS perlu menambah cabang atau kantor kas untuk meningkatkan pengembangan supaya lebih baik lagi, hingga saat 
ini BPRS Hasanah belum menambah cabang, yang sebenarnya BPRS bisa berkembang lebih baik lagi.

\section{DAFTAR PUSTAKA}

Adrian Sutedi, 2009, Perbankan Syariah: Tinjauan Dan Beberapa Segi Hukum, Cet. 1. Jakarta: Ghalia Indonesia

Al-Kasany, 2005, Badai' Ash-Shanai' fi Tartib Asy-Syarai', Kairo: Darul Hadits

Al-Marghinany, 2000, Al-Hidayah Syarh Bidayatul Mubtadi, Beirut: Darul Kutub Al-Ilmiyah

An-Nawawy, 2004, Al-Majmu'Syarh Al-Muhazdzdab, Beirut: Darul Fikr

Fatwa DSN MUI No. 04/DSN-MUI/IV/2000

Fatwa DSN MUI No. 13/DSN-MUI/IX/2000

Fatwa DSN MUI No. 16/DSN-MUI/IX/2000

Fatwa DSN MUI No. 17/DSN-MUI/IX/2000

Fatwa DSN MUI No. 23/DSN-MUI/III/2002

Fatwa DSN MUI No. 46/DSN-MUI/II/2005

Fatwa DSN MUI No. 47/DSN-MUI/II/2005

Fatwa DSN MUI No. 48/DSN-MUI/II/2005.

Heri Sudarsono, 2004, Bank dan Lembaga Keuangan Syariah Deskripsi dan Ilustrasi, Yogyakarta: Ekonisia

Ibnu Manzhur, 2005, Lisanul Arab, Beirut: Darul Kutub Al-Ilmiyah, 2005.

Ibnu Qudamah, Al-Mughny, Kairo: Darul Hadits

Ibrahim Warde, 2009, Islamic Finance Keuangan Islam Dalam Perekonomian Global terj. Andriyadi Ramli, Yogyakarta : Pustaka Pelajar

Kementrian Wakaf dan Urusan Islam, 2006, Al-Mausu'ah Al-Fiqhiyah, 2006.

Latifa M. Al-Gaoud dan Mervyn K. Lewis, 2004, Perbankan Syariah Prinsip Praktek Prospek terj. Burhan Wira Subrata, Jakarta: PT. Serambi Ilmu Semesta

Muhammad Syafi'i Antonio, 2001, Bank Syariah dari Teori ke Praktek, Jakarta: Gema Insani Press 
Islamic Business and Finance (IBF), Vol. 1, No.2, Oktober 2020

Sugiono, 2012, Statistika Untuk Penelitian, Bandung: Alfabeta

UUD No. 21 Tahun 2008, Tentang Perbankan Syariah

Wawancara dengan Bpk. Edwin Hendra Kepala Bagian Pembiayaan PT. BPRS Hasanah Pekanbaru. 